Hilgartner, "Harry EImer Barnes" 19

\title{
Harry Elmer Barnes Historical Review and the effects of Historical Revisionism
}

Jacob Hilgartner

Harry Elmer Barnes remains a controversial figure and is a prime example of historical revisionism and the effects it can have on historical works. Harry E. Barnes would start his career as an American historian who focused on a broad range of subjects in terms of social conflicts and would deliver works on everything from criminology to American foreign policy. ${ }^{1}$ He was known for the great volume and speed with which he produced publications. His work $A$ History of Western Civilization (1935) would be mentioned in the New York Times Book Review section's front page. ${ }^{2}$ His works would find publishers such as Knopf, Prentice-Hall, and Century avidly seeking their distribution. Other well-regarded writers of the time such as Heywood Braun, and Sinclair Lewis would often include Barnes in their intellectual circles. Barnes became one of Americas most sought-after lecturers of the 1920-1930s. ${ }^{3}$

Evidently, Barnes was not a pariah from the outset, nor was he an entrenched conservative ideologue. Barnes himself would have been viewed as a progressive even by todays standard, with many of his works advocating equality for woman and for the African American communities, whose treatment by the American state was a stain on the ideals of liberty it tried to espouse. ${ }^{4}$ He was a staunch opponent of prohibition and advocated for a reworking of prison reform, a reworking of drug use legislation, and the abolition of sexual taboo laws. ${ }^{5}$ However, his anti-interventionist stance in the 1940s derailed his career.

Barnes' article “Europe's War and Our Democracy” demonstrates best his antiinterventionist perspective. Barnes argued against what he described as a "fifth column racket," wherein anyone who would speak out against the perceived norms of the time would be labelled as a saboteur of the war effort and would be buried under accusation. ${ }^{6}$ Barnes writes that in wake of the civil injustices and manhunts of the First World War that a second would bring about further destruction of civil liberties and dissidents would find themselves discordant with the populism growing in America. ${ }^{7}$ Writing about the aftermath of the First World war, Barnes was sympathetic to the Germans because of the terms of the "the vindictive treaty Versailles." 8 These Terms had pushed Germany to adopt a radical and totalitarian government. ${ }^{9}$ Barnes blamed this mostly on the French and British governments' refusal to accept some measured responsibility for the war but also America for intervening and making a war without total victory impossible, allowing the allies to sue for more punishing terms onto Germany in the face of annihilation. ${ }^{10}$

${ }^{1}$ Doenecke, Justus D. "Harry Elmer Barnes." The Wisconsin Magazine of History 56, 4. (1973): 311.

${ }^{2}$ Doenecke, "Harry Elmer Barnes.", 311.

3 Doenecke, "Harry Elmer Barnes.", 311.

${ }^{4}$ Doenecke, "Harry Elmer Barnes.", 312.

${ }^{5}$ Doenecke, "Harry Elmer Barnes.", 312.

${ }^{6}$ Barnes, Harry Elmer. "EUROPE'S WAR AND AMERICA'S DEMOCRACY.” The Virginia Quarterly Review 16, 4. (1940): 561.

${ }^{7}$ Barnes, "EUROPE'S WAR AND AMERICA'S DEMOCRACY.”, 560.

${ }^{8}$ Barnes, "EUROPE'S WAR AND AMERICA'S DEMOCRACY.", 555.

${ }^{9}$ Barnes, "EUROPE'S WAR AND AMERICA'S DEMOCRACY.", 555.

${ }^{10}$ Barnes, "EUROPE'S WAR AND AMERICA'S DEMOCRACY.”, 555. 
In relation to contemporary events, Barnes argued against the British claim that following their fall to the oncoming Nazi onslaught that America would be next, instead arguing that an immediate attack on America after the fall of the Old World is not pragmatic and that by declaring war the US would risk a possible unification of totalitarian powers across the globe against the US. ${ }^{11}$ Barnes also maintained that the Old World (as of the disaster of World War One) did not have the strength to uphold democracy and that the Western Hemisphere could not suffer the same fate. ${ }^{12}$ Barnes also argued that had Britain and France not declared war following the invasion of Poland, Germany would have left France alone, stating that Hitler's main ambition was always to the east in Russia and that aggressive policies had led to the tragedy of the French defeat and Britain's self-inflicted predicament.

At the time of this article's creation France had been defeated and occupied by Germany, with the British fearing an invasion during the bombing campaign of the coming Battle of Britain and the retreat at Dunkirk. The German Nazi state and military at this time would have been viewed as aggressors by most contemporary writers, making Barnes' apologetic stance towards Germanies actions controversial and by todays standards highly revisionist. American foreign policy at this time was still noninterventionist, but the growing threat of Japan in the East and fears of rising European totalitarianism had seen the American government under FDR begin to supply the allies with war material and a growing question of whether to enter the war being put forward in congress. This would affect the atmosphere in which Barnes would have written about the dangers of entering a conflict that at the time felt closer each day.

Barnes advocated that America stop playing the part of the world's school master, arguing that it cannot hope to effectively police the entire world. Barnes would remark that a joint venture such as the League of Nations was needed and that the US had blundered by leaving it to die. ${ }^{13}$ In the context of the time the US had emerged as a dominate superpower as of World War One and its ability to affect the global community had been put on display with the creation of the League of Nations, despite its later withdrawal into pseudo-isolationism. In a certain light, Barnes' view came to haunt US foreign policy during the Cold War and after as an interventionist America would be drawn into a series of global conflicts. This accurate prediction by Barnes has caused many to cite him as a credible source which becomes problematic when considering his other theories.

Barnes' main argument was that intervention in the Second World War would create intellectual conformity in both academics and politics such that the freedoms and liberties of those not working towards interventionist goals would be suppressed and derided as the dreaded "fifth Column". ${ }^{14}$ This was not baseless as during World War One Woodrow Wilsons government greatly and at times violently suppressed anti war demonstrations and activities, denouncing them as seditious activities. Barnes had also experienced state repression based on intellectual positions. His public criticism of the FBI's inability to handle organized crime and the hubris involved in the Dillinger case caused him to become viewed by the FBI as an enemy and he was investigated for being a German-sympathizing Fifth Columnist. ${ }^{15}$

\footnotetext{
${ }^{11}$ Barnes, "EUROPE'S WAR AND AMERICA'S DEMOCRACY.", 559.

12 Barnes, "EUROPE'S WAR AND AMERICA'S DEMOCRACY.”, 559.

${ }^{13}$ Barnes, "EUROPE'S WAR AND AMERICA'S DEMOCRACY.", 552-62.

${ }^{14}$ Barnes, "EUROPE'S WAR AND AMERICA'S DEMOCRACY.", 561.

15 Turnbaugh, Roy. "The FBI and Harry Elmer Barnes: 1936-1944." The Historian 42, no. 3 (1980): 385-98. www.jstor.org/stable/24445964.
} 
Barnes' German sympathies would play a large role in his writings and activities after the entry of the US into the Second World War following the events of Pearl Harbor. Even after 1945, Barnes would continue to denounce US interventionism and excuse or deny war crimes carried out by the Nazi regime. ${ }^{16}$ Barnes went so as far as blaming an internment camp survivor for his internment by the Nazi regime, stating that it was his bias and hatred for the Nazis was the key cause of his internment. ${ }^{17}$ This obsession would see Barnes labelled as a revisionist and become a pariah by the 1950s. This condemnation in turn made him more ardent in his expressions of fear about the Fifth Colum racket's perceived influence. ${ }^{18}$

Other revisionist and right-wing conspirators would often use his work and communicate with Barnes, no doubt helping fuel Holocaust denial that emerged in many countries after the war. ${ }^{19}$ Collaboration with like-minded people resulted in the publication of Perpetual War for Perpetual Peace: A Critical Examination Of The Foreign Policy Of Franklin Delano Roosevelt And Its Aftermath with Barnes as the main editor. In this work, Barnes and several other revisionists attempted to link the supposed aggressiveness of Franklin Roosevelt's foreign policy for the events of the Second World War. ${ }^{20}$ Barnes makes bold claims, insisting that the United States was a "libertarian country in which there were little or no witch-hunting and few of the symptoms and operations of the police state which have been developing here during the last decade. Not until our intervention in the First World War had there been sufficient invasions of individual liberties to call forth the formation of special groups and organizations to protect our civil rights." ${ }^{21}$ Barnes calls for historical revisionism: since revisionists were proven correct in their view of the events surrounding the First World War in Barnes' opinion, then revisionist views of the Second World War Two would be no different. ${ }^{22}$ There was, however, a perceived great danger that haunted Second World War revisionists according to Barnes. Using his own case as proof, Barnes claimed that any detraction from the mainstream view of war guilt or war crimes could see the destruction of one's career and livelihood. ${ }^{23}$

Barnes' academic background and former reputation within the discipline of History also helps to lend credibility to his revisionist views. They can seem convincing to those who do not have a firm grasp of how to spot the flaws in Barnes' work. This, therefore, allows it to be used as a tool to support Holocaust denial and silence detractors who do not have the knowledge required to counter Barnes' accusations. This is the danger of historical revisionism: access to reliable information and the ability to assess claims is strongest among those trained in the

${ }^{16}$ Doenecke, Justus D. “Harry Elmer Barnes.” The Wisconsin Magazine of History 56, 4. (1973): 315.

${ }^{17}$ Barnes, Harry Elmer. "[Letter from Harry Elmer Barnes].” The Annals of the American Academy of Political and Social Science 267 (1950): 253-54.

${ }^{18}$ Doenecke, Justus D. "Harry Elmer Barnes.” The Wisconsin Magazine of History 56, 4. (1973): 316.

${ }^{19}$ Doenecke, Justus D. "Harry Elmer Barnes.” The Wisconsin Magazine of History 56, 4. (1973): 316.

${ }^{20}$ Barnes, Harry Elmer. 2016. Perpetual War for Perpetual Peace: A Critical Examination Of

The Foreign Policy Of Franklin Delano Roosevelt And Its Aftermath. San Francisco: Hauraki

Publishing. ProQuest Ebook Central.

${ }^{21}$ Barnes, Perpetual War for Perpetual Peace, 3.

22 Barnes, Perpetual War for Perpetual Peace, 3.

${ }^{23}$ Barnes, Perpetual War for Perpetual Peace, 3. 
discipline of History. Among the masses with access to the internet, Barnes' work continues to circulate with disinformation being touted as fact.

Barnes was also a participant in the creation of outright conspiracy theories and helped to give a platform to those who claimed that Franklin D. Roosevelts' actions resulted in the events of Pearl Harbor. Barnes himself was a consistent supporter of the theory that FDR had allowed Pearl Harbor to happen and had colluded with British Prime Minister Winston Churchill to silence any warning that an attack by Japan was imminent. ${ }^{24}$ It would only be on his death bed that he would rescind the comment that the president had done this openly, settling for an opinion that it was done less overtly. ${ }^{25}$

This style of conspiratorial thinking would be a model for future American revisionist theories and helped create the theory of an elitist establishment working to create an information blackout through a myriad of powerful pressure groups and institutions aimed at suppressing American scholars from revealing what Barnes considered the real truth. ${ }^{26}$ This belief was compounded by the refusal to publish both the manuscripts written by Barnes as well as those written by other revisionists which were in contrast to the relatively easier path to publication of First World War revisionist manuscripts. ${ }^{27}$ This led Barnes and other revisionist writers such as Charles A. Beard to conclude that a greater conspiracy was pitted against them. ${ }^{28}$ Having nowhere to publish his works, he resorted to privately publishing them. These self-publications included his most controversial and revisionist statements such as blaming McCarthyism on the totalitarian warmongering of the perceived growing liberal establishment. ${ }^{29} \mathrm{He}$ believed that in their lack of tolerance towards anyone's view but their own they had perpetuated the red scare and that the Democratic Party's condemnation of Senator McCarthy and the House Committee on Un-American Activities was hypocritical given their position towards dissent. ${ }^{30}$ This worldview would help further push Barnes to pit his work towards against a global conspiracy he believed was headed by the liberal establishment. His inability to find publishers for his works and find employment was ultimate proof in his eyes.

Barnes' career demonstrates how revisionism can cause historical writers to become embittered, much to the detriment of their work. Barnes' ability to predict but inability to properly analyze global events shows why context and perspective, as well as a measure of

\footnotetext{
${ }^{24}$ Ruetten, Richard T. "Harry Elmer Barnes And the "Historical Blackout"." The Historian 33, 2. (1971): 202-14. www.jstor.org/stable/24442669.

${ }^{25}$ Ruetten, "Harry Elmer Barnes And the "Historical Blackout".", 202-14. www.jstor.org/stable/24442669.

${ }^{26}$ Ruetten, "Harry Elmer Barnes And the "Historical Blackout".", 202-14. www.jstor.org/stable/24442669.

${ }^{27}$ Ibid.

${ }^{28}$ Ibid.

${ }^{29}$ Barnes, Harry Elmer. 1953. The Chickens Of The Interventionist Liberals Have Come Home To Roost. The Internet Archive.

https://archive.org/details/TheChickensOfTheInterventionistLiberalsHaveComeHomeToRoost/p age/n1/mode/2up

${ }^{30}$ Barnes, The Chickens Of The Interventionist Liberals Have Come Home To Roost. Archive.https://archive.org/details/TheChickensOfTheInterventionistLiberalsHaveComeHomeTo Roost/page/n1/mode/2up
} 
emotional distance, can be required to accurately represent these events. Bias will always be present in any field and it is tied to an academic no matter how sterile they make themselves out to be, so to counter Historical revisionism, the first step must be for any writer discussing history the bias held within them must be recognized. 


\section{Bibliography}

Barnes, Harry Elmer. "[Letter from Harry Elmer Barnes]." The Annals of the American Academy of Political and Social Science267 (1950): 253-54. www.jstor.org/stable/1026816.

Barnes, Harry Elmer. "EUROPE'S WAR AND AMERICA'S DEMOCRACY." The Virginia Quarterly Review 16, no. 4 (1940): 552-62. www.jstor.org/stable/26448392.

Doenecke, Justus D. "Harry Elmer Barnes." The Wisconsin Magazine of History 56, no. 4 (1973): 311-23. www.jstor.org/stable/4634822.

Barnes, Harry Elmer. Perpetual War for Perpetual Peace: A Critical Examination of the Foreign Policy of Franklin Delano Roosevelt and its Aftermath. San Francisco: Hauraki Publishing, 2016. Proquest Ebook Central.

Ruetten, Richard T. "Harry Elmer Barnes and the "Historical Blackout"." The Historian 33, no. 2 (1971): 202-14. www.jstor.org/stable/24442669.

Barnes, Harry Elmer. 1953. The Chickens Of The Interventionist Liberals Have Come Home To Roost. The Internet Archive. Accessed August 10, 2020. https://archive.org/details/TheChickensOfTheInterventionistLiberalsHaveComeHomeTo Roost/page/n1/mode/2up

Turnbaugh, Roy. "The FBI and Harry Elmer Barnes: 1936-1944." The Historian 42, no. 3 (1980): 385-98. www.jstor.org/stable/24445964. 